\title{
First Evidence of Intracellular Bacteria Cardinium in Thermophilic Mite Microzetorchestes emeryi (Acari: Oribatida): Molecular Screening of Bacterial Endosymbiont Species
}

\author{
Edyta Konecka ${ }^{1} \cdot$ Ziemowit Olszanowski $^{2}$
}

Received: 11 December 2018 / Accepted: 6 June 2019 / Published online: 18 June 2019

(c) The Author(s) 2019

\begin{abstract}
We undertook the issue of the distribution of intracellular bacteria among Oribatida (Acari). Six genera of bacteria were detected by PCR and Sanger DNA sequencing: Wolbachia, Cardinium, Rickettsia, Spiroplasma, Arsenophonus, and Hamiltonella. Our research, for the first time, revealed the presence of Cardinium in Microzetorchestes emeryi in two subpopulations separated from each other by $300 \mathrm{~m}$. The percentages of infected animals were the same in both subpopulations-ca. $20 \%$. The identity of $16 \mathrm{~S}$ rDNA sequences of Cardinium between these two subpopulations of $M$. emeryi was $97 \%$. Phylogenetic analysis showed that the Cardinium in M. emeryi was clustered into the group A. The occurrence of M. emeryi in Poland has not been reported before and our report is the first one. Cardinium maybe help the thermophilic M. emeryi to adapt to low temperatures in the Central Europe.
\end{abstract}

\section{Introduction}

Many bacterial species stay in close relationships with various invertebrate hosts, often establishing a persistent association. Symbiosis has an important role in the evolution of partners that are involved in the relation. The interplay of both organisms or, in some cases, between a host and more than one symbiotic bacterium, forms an evolving community that changes throughout time [1]. Sometimes, the relationship between host and bacterium is difficult to study, as some microorganisms are intracellular and cannot be cultured using standard bacteriological media under laboratory conditions [2]. Intracellular symbiosis is either obligate or facultative. Obligate endosymbionts are essential for hosts to survive and generally have long evolutionary histories with the organisms they live into [3]. Facultative endosymbionts can affect invertebrate's development, reproduction [4], or protection from natural enemies [1,5]. Endosymbiotic

Edyta Konecka

edkon@amu.edu.pl

1 Department of Microbiology, Faculty of Biology, Adam Mickiewicz University in Poznań, Umultowska 89, 61-614 Poznan, Poland

2 Department of Animal Taxonomy and Ecology, Faculty of Biology, Adam Mickiewicz University in Poznań, Umultowska 89, 61-614 Poznan, Poland infection might even improve the pesticide resistance of hosts [6].

The oribatid mites (Oribatida: Acari) are one of the most abundant and common arthropod groups occurring in soil habitats [7]. However, the information of the endosymbiotic bacteria in these mites is poor. Intracellular microorganisms were found only in three oribatid species: Oppiella nova [8], Hermannia gibba [9], and Achipteria coleoptrata [10]. The role of the bacterial partners has not been discovered. It is especially interesting as these mite species are parthenogenetic [7] and some symbionts were found to be associated with parthenogenesis in arthropods [11-13]. Vertically transmitted bacteria Wolbachia [11], Rickettsia [12], and Cardinium [13] may change the way of reproduction of arthropods from sexual to parthenogenetic. Other maternally inherited bacteria are Spiroplasma, Arsenophonus [14], and Hamiltonella [15]. The richness of functions that intracellular bacteria can perform for their hosts is enormous. Some of them can eliminate males from the animal population also by male-killing, feminization, or cytoplasmic incompatibility. Some effects induced by bacteria do not affect reproduction or change in the number of males, but may affect nutritional balance [16]. The microorganisms may even protect invertebrates against viruses [17].

The intracellular bacteria of invertebrates can be detected by methods based on PCR and Sanger DNA sequencing [18-23]. Primers targeting the partial sequences of $16 \mathrm{~S}$ 
rDNA have been established for detecting Wolbachia [18], Cardinium [19], Rickettsia [20], Spiroplasma [21], Arsenophonus [22], and Hamiltonella [23]. Sequencing of bacterial 16S rDNA is a universal tool for phylogenetic analysis of bacteria and molecular evolutionary research. It allows characterizing microorganisms in a diverse range of hosts and investigating relationships between bacteria. The analysis of $16 \mathrm{~S}$ rDNA has discriminatory power and ability to classify strains into phylogenetic groups. An example is Cardinium. Based on 16S rRNA data, the genus has been divided into groups A, B, C [24], D [25, 26], and E [10].

We undertook the issue of the distribution maternally inherited bacteria among oribatid mites to fulfil the gap in the information about the occurrence of intracellular microorganisms in this group of mites. The endosymbionts were detected in mites isolated from soil samples of forest situated inside a town. We searched for Wolbachia, Cardinium, Rickettsia, Spiroplasma, Arsenophonus, and Hamiltonella by using PCR method. Phylogenetic analysis of Cardinium was based on 16S rRNA gene. A hypothesis " $M$. emeryi posses intracellular bacterial endosymbionts that were previously described in arthropods host species" was tested.

\section{Materials and Methods}

\section{Collecting of Oribatida}

Oribatid mites were collected from litter and soil samples (six samples from both localities to the depth of $10 \mathrm{~cm}$ ) obtained in an urban mixed forest in the northern part of Poznań, Poland $\left(52^{\circ} 27^{\prime} \mathrm{N} 16^{\circ} 56^{\prime} \mathrm{E}\right)$ of a temperate climate with relatively cold winters and warm summers. Tree species there were: pine (Pinus sylvestris), oak (Quercus robur), bird cherry (Prunus padus), and robinia (Robinia pseudoacacia). Samples were gathered from two mite localizations separated from each other by $300 \mathrm{~m}$, representing similar type of vegetation and soil type, from May to July in years 2013-2016. Mites were extracted by using high-gradient Tullgren funnels, segregated intravitally and immediately placed directly in $96 \%$ ethanol. Comparative specimens were conserved in $70 \%$ ethanol and then, after clearing in lactic acid, identified to the species or genus level by using the Weigmann key [27]. Over 100 individuals belonging to the following families of oribatid mites were subjected to molecular testing: Hypochthoniidae, Nothridae, Camisiidae, Gymnodamaeidae, Damaeidae, Oppiidae, Carabodidae, Achipteriidae, Oribatulidae, Scheloribatidae, and Galumnidae.

\section{Screening of Bacterial Endosymbionts in Mites}

The detection procedures of Cardinium, Wolbachia, Arsenophonus, Spiroplasma, and Rickettsia were described in detail previously [8]. DNA was extracted from a pool of 2-10 specimens by using Genomic Mini kit for universal genomic DNA isolation (A\&A Biotechnology) according to the manufacturer's instruction. Bacteria were detected using PCR. A reaction mixture contained 10-30 ng of DNA, 1x PCR buffer (Novazym), $0.2 \mathrm{mM}$ dNTP (Novazym), $0.6 \mu \mathrm{M}$ each primer (Oligo.pl), $0.4 \mathrm{U}$ HiFi Taq polymerase (Novazym), and sterile bidistilled water to a total volume of $10 \mu \mathrm{l}$. Negative controls with no DNA were included in each reaction. Positive control of DNA isolation and PCR reaction was amplification of the mite 28S rRNA gene [28]. Wolbachia [29], Cardinium [30], and Spiroplasma [31] were detected by $16 \mathrm{~S}$ rDNA sequencing. Rickettsia was detected by sequence analysis of the gene coding for Rickettsia $17 \mathrm{kDa}$ protein antigen [32]. 23S rRNA gene was amplified for Arsenophonus detection [33]. The presence of Hamiltonella was determined by Hamiltonella chromosomal replication initiator protein [34]. PCR reactions were performed in a MyCycler thermal cycler (Bio-Rad). Amplicons were electrophoresed (Agarose NOVA Mini, Novazym) with a Nova 100 bp DNA Ladder (Novazym). Electropherograms were documented with the Bio-Print V.99 system (Vilber Lourmat). PCR products were directly sequenced or cloned by using TOPO TA Cloning Kit for Sequencing (Invitrogen) in accordance with the manufacturer's instructions before sequencing. Sequencing were performed with BigDye Terminator v3.1 on an ABI Prism 3130XL (Applied Biosystems) and the sequences were compared to the available GenBank data (International Nucleotide Sequence Database Collaboration) by using BLASTn. The 326-bp 16S rDNA sequence of Cardinium in M. emeryi was deposited in GenBank under Accession No. KY039581.

\section{Phylogenetic Analysis of Cardinium}

Phylogenetic analysis was performed based on 16S rDNA gene sequences. DNA was extracted from an individual specimen as described above. Because there is no noticeable external dimorphism in most oribatid mites (including Microzetorchestes emeryi), sex could be determined by examining the genitalia, which were usually retracted within the body. Unfortunately, this is not possible without lactic acid clearing of all specimens, which prevents later molecular procedures.

Detection of the gene was performed in $15 \mu \mathrm{l}$ containing 10-30 ng of template DNA, 1x PCR DreamTaq Buffer (Thermo Scientific), $0.2 \mathrm{mM}$ dNTP (Novazym), $0.75 \mu \mathrm{M}$ each primer from one of the primer sets (Oligo.pl), and $0.4 \mathrm{U}$ DreamTaq Hot Start DNA Polymerase (Thermo Scientific). The Cardinium 16S rDNA gene was amplified (1) with specific primer $\mathrm{Ch}-\mathrm{F}$ and universal eubacterial primer $1513 \mathrm{R}$ [30], and (2) with the specific primer Ch-R and universal eubacterial primer $63 \mathrm{~F}$ [35]. PCR products were analysed 
by electrophoresis, sequenced and compared with the available GenBank sequence data as described above. 16S rDNA sequences of Cardinium in M. emeryi from two subpopulations separated from each other by $300 \mathrm{~m}$ were deposited in GenBank under Accession No. MG889458 and MG889459.

The phylogenetic relationship of Cardinium from $M$. emeryi and other arthropod hosts was analysed using 45 16S rDNA sequences of Cardinium available in GenBank, including those detected in this study. Our aligned dataset consisted of $16 \mathrm{~S}$ rDNA sequences of Cardinium symbionts from 28 insect hosts, 16 mite hosts including M. emeryi, one nematode, and one crustacean host. Sequences of Amoebophilus asiaticus, Bacteroidetes, and endosymbiont of Acanthamoeba sp. were used as an outgroup. The sequences were aligned with the use of CLUSTAL W with MEGA 6.06 software [36]. The appropriate model of sequence evolution was chosen using jModelTest 2.0 software [37]. The Hasegawa-Kishino-Yano model with C-distributed rates and invariant sites $(\mathrm{G}+\mathrm{I})$ was selected to compute genetic distances (base substitutions per site) [36]. The phylogenetic tree was constructed with the maximum-likelihood method and the bootstrap support was determined with 1000 bootstrap replicates.

\section{Results}

This is the first report of Cardinium in Microzetorchestes emeryi. The bacterium was found in $M$. emeryi isolated from metapopulation. In the phylogenetic analysis using two pairs of primers $\mathrm{Ch}-\mathrm{F}+1513 \mathrm{R}$ and $\mathrm{Ch}-\mathrm{R}+63 \mathrm{~F}$, the bacterial 16S rDNA sequences with the length of $1443 \mathrm{bp}$ and $1296 \mathrm{bp}$ were obtained from mites of two subpopulations separated from each other by $300 \mathrm{~m}$. The sequence of $1443 \mathrm{bp}$ was obtained for Cardinium in M. emeryi from one subpopulation and the sequence of $1296 \mathrm{bp}$ was obtained for Cardinium in M. emeryi from second subpopulation. These sequences were deposited in GenBank under Accession No. MG889458 and MG889459, respectively. This is the first report of this bacterium in $M$. emeryi. We examined $15 \mathrm{spec}-$ imens of M. emeryi from each subpopulation. Three of them were infected in each subpopulation. Other bacterial symbionts (Rickettsia, Spiroplasma, Arsenophonus, and Hamiltonella) were not found in the examined mite individuals.

The $\mathrm{G}+\mathrm{C}$ content of Cardinium 16S rDNA sequences was $49 \%$. Within $16 \mathrm{~S}$ rDNA, two sequences unique to the bacterium: 5'-GCGGTGTAAAATGAGCGTG-3' and 5'-GGTCTTTAACTGACGCT-3' [38] were found in Cardinium of $M$. emeryi in both subpopulations. The signature sequence for 16S rDNA of Cardinium 5'-GTATTT TGCTACTTTG-3' designated by Zchori et al. [38] was not found in the sequence of the bacteria of M. emeryi.
Instead, similar sequence 5'-GTATTTTGCCACCTTG-3' was found in Cardinium 16S rDNA of M. emeryi from both subpopulations.

The comparison of $16 \mathrm{~S}$ rDNA sequences of Cardinium in M. emeryi with those in other arthropod hosts, deposited in GenBank, by using BLASTn revealed that the sequence of Cardinium in M. emeryi of one subpopulation (Accession No. MG889458) was most similar to sequences of Bateroidetes endosymbiont of mite Metaseiulus occidentalis (Accession No. AY753170 and AY753169) with 98\% identity and $0.0 \mathrm{E}$ value. Within $16 \mathrm{~S}$ rDNA of Cardinium of $M$. occidentalis, the first sequence of the unique to the bacterium was found. The second unique sequence and the signature sequence differed in one nucleotide and were as follows: 5'-GGTCTTTGACTGACGCT-3' and 5'-GTA TTTTGCTACCTTG-3', respectively. The 16S rDNA of Cardinium in $M$. emeryi of the second subpopulation (Accession No. MG889459) showed highest similarity to the uncultured bacterium of mite Dermatophagoides farinae (Accession No. JN236339), Bacteroidetes endosymbiont of mite Metaseiulus occidentalis (Accession No. AY753170), and Cardinium of insect Bemisia tabaci (Accession No. LC159289) with 97\% identity and $0.0 \mathrm{E}$ value. Within $16 \mathrm{~S}$ rDNA of Cardinium of $D$. farinae and $B$. tabaci two unique sequences to the bacterium were found. The signature sequence of Cardinium in D. farinae differed in one nucleotide and it was 5'-GTGTTTTGCTAC CTTG-3'. The signature sequence of the bacterium from B. tabaci was identical to that found in Cardinium from $M$. emeryi. The similarity of sequences of Cardinium in. $M$. emeryi of both subpopulations was also high with identity $97 \%$ and $0.0 \mathrm{E}$ value. We also compared the sequences of Cardinium 16S rDNA of M. emeryi of both subpopulations, Oppiella nova (Accession No. AY279414), and Achipteria coleoptrata (Accession No. MG889457) as they are Cardinium hosts representing Oribatida. The similarities of sequences were high with identity $93-98 \%$. Within $16 \mathrm{~S}$ rDNA of Cardinium of 0 . nova, the first unique sequence to the bacterium was not found, whereas the second one was noted. The signature sequence in Cardinium from $O$. nova differed in two nucleotides and it was 5'-GTGTTTTGCTACCTTG-3'. The first of the unique sequence was noted in Cardinium from A. coleoptrata. In the second unique sequence, Konecka \& Olszanowski [10] found one nucleotide substitution in the 7th position (A instead of T) and this sequence was 5'-GGTCTTAAA CTGACGCT-3'.

The phylogenetic analysis revealed Cardinium of $M$. emeryi belonged to group A with the nearest branch of Cardinium in B. tabaci (Fig. 1). Cardinium found in other oribatid host-O. nova was also clustered within group A, together with Cardinium in M. emeryi. 


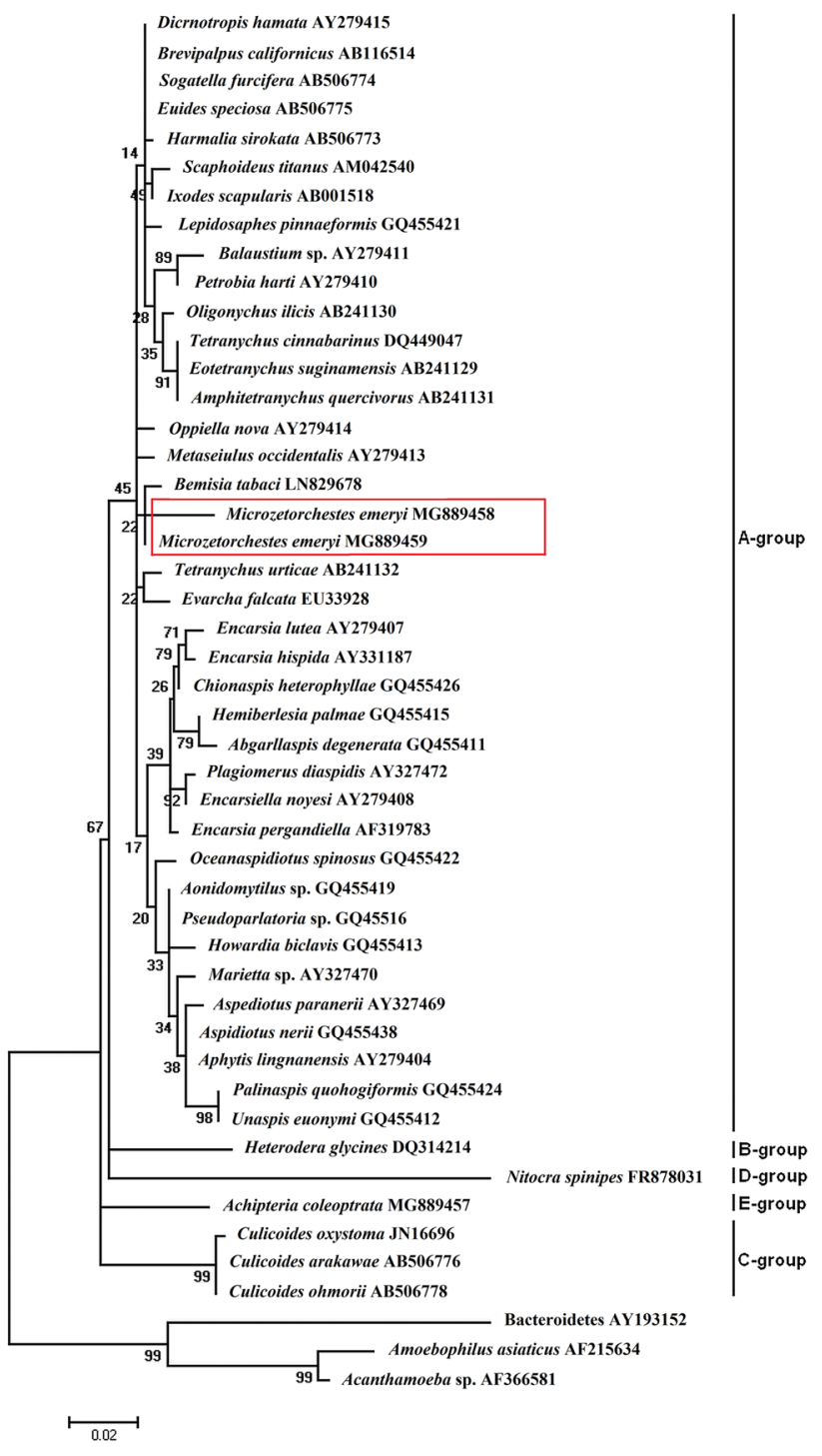

Fig. 1 Phylogeny based on the sequences of Cardinium 16S rDNA gene. Strains of Cardinium were designated by the names of their host. Amoebophilus asiaticus, Bacteroidetes, and endosymbiont from Acanthamoeba sp. were used as an outgroup. Bar, substitutions per nucleotide. Bootstrap values based on 1000 replicates are shown on the branches

\section{Discussion}

The study concerns distribution of microorganisms living inside Oribatida mites. Bacteria Cardinium were detected, for the first time, in oribatid mites Microzetorchestes emeryi from two subpopulations of metapopulation. The percentages of infected animals were the same in both subpopulation-ca. $20 \%$. Similar rate of bacterial occurrence was observed in other arthropod hosts [24, 39]. However, in some invertebrate populations, the frequency of Cardinium prevalence was higher $[24,40]$. Finding uninfected individuals indicated that the bacteria do not function as primary symbionts. The G-C content (49\%) was the same in 16S rDNA of Cardinium from M. emeryi of both subpopulations and in Cardinium previously found in other arthropods [24]. The bacterial strains infecting M. eme$r y i$ from neighbouring places were similar based on $16 \mathrm{~S}$ rDNA sequences to bacteria found in mite Metaseiulus occidentalis and insect Bemisia tabaci. The sequences of Cardinium 16S rDNA in mites Oppiella nova and Achipteria coleoptrata also showed high level of similarity to Cardinium in M. emeryi representing the same order Oribatida.

Although the sequences of $16 \mathrm{~S}$ rDNA of Cardinium strains from $M$. emeryi of neighbouring subpopulations differed, they showed high level of similarity $97 \%$. Phylogenetic analysis revealed that the bacteria were closely related and formed sister branches together with Cardinium of $B$. tabaci (Fig. 1). No data, except from 16S rDNA sequence deposited in GenBank, are available on the Cardinium strain in B. tabaci from the sister branch of Cardinium in $M$. emeryi and no information was given on its impact on its insect host. The role of the endosymbiont in the insect is unclear and has not been discovered. However, other Cardinium strains were not proven to be feminization, cytoplasmic incompatibility, and parthenogenesis inductors in B. tabaci [41], but their function in the insect male-killing was suspected [23]. Some literature data suggest that $\mathrm{Car}$ dinium may be a mutualistic symbiont [42], whereas other data indicate opposite symbiotic relation [41]. The bacterial beneficial abilities for the insect host probably are related to Cardinium motility and toxin synthesis. The genome of the symbiont of $B$. tabaci includes gliding genes that are related to bacterial motility and also the putative toxin-related genes encoding proteins related with bacterial insecticidal toxins. Due to the motility feature, Cardinium may directly contact a host's parasitoid and kill it by secreting toxins [26]. Other literature data revealed negative role of Cardinium in $B$. tabaci. The Cardinium-free insects had higher fitness than Cardinium-infected B. tabaci [41]. It cannot be excluded that the action of bacteria may depend on Cardinium strain, its properties, and/or the B. tabaci population and the characteristic features of insects belonging to the population. In M. emeryi metapopulation, the Cardinium role of inducing parthenogenesis, feminization, and male-killing could be rejected as M. emeryi is a sexual species [43]. M. emeryi is a thermo-xerophilous species [44] and has a more southern distribution in Europe [27, 45]. There is no literature data on the occurrence of this mite in Poland. We detected, for the first time, two neighbouring localizations of M. eme$r y i$ in an urban, mixed forest in the north-western part of Poland. Additionally, in both subpopulations infected mites were found. The occurrence of M. emeryi in Poland is enigmatic. The Polish climate is mostly temperate. The winter 
temperatures dropped to around $-6{ }^{\circ} \mathrm{C}$ in the last few years and with average rainfall during few last years of ca. $600 \mathrm{~mm}$ (data from the website of The Institute of Meteorology and Water Management-National Research Institute). Although the average temperatures are rising [46], it is still difficult to explain why $M$. emeryi mites that prefer rather warm and dry climate of Mediterranean regions were observed in Central Europe. The phenomenon of global warming resulting in the emergence of southern species in Polish fauna and flora could be also important. Perhaps $M$. emeryi is a relatively recent component of the local fauna. Did Cardinium have an impact on the survival of their hosts at low temperatures? It has been shown that temperature change may influence the community of symbiotic bacteria in invertebrates. The dominant bacterial species in different generations of insects are stable under low temperatures, but can significantly change under high temperatures. High temperature reduces the number of some symbiotic bacterial species in insects [47]. Possibly, the microbes allow surviving invertebrates at low temperatures and this is why the changes in the species composition of the host's microbiome due to temperature changes were observed. Cardinium maybe help the M. emeryi mites to adapt to low temperatures in the Central Europe. It seems interesting that $B$. tabaci originated from tropical and subtropical regions and additionally one of the $B$. tabaci geographically defined clade is Mediterranean [48]. Now the insect is widely distributed in temperate areas including most of Europe [49]. Although there is no evidence for endosymbiont contribution in insect adaptation to colder and harsher climate, the history of $M$. emeryi and $B$. tabaci moving from dry summer to tepid regions is similar and the scenario of microbiome helpful role in their spreading cannot be excluded.

In conclusion, our research, for the first time, revealed the presence of Cardinium in oribatid mites $M$. emeryi in two subpopulations of metapopulation. Phylogenetic analysis showed that the bacteria clustered with Cardinium of other invertebrate hosts in group A. They were closely related and formed sister branches together with Cardinium of B. tabaci. The role of the endosymbiont in the mites is unclear. Possibly, the bacterium is the key to explaining the mystery of the occurrence of these thermophilic mites in the colder climate of Central Europe.

\section{Compliance with Ethical Standards}

Conflict of interest The authors declare that they have no conflict of interest.

Open Access This article is distributed under the terms of the Creative Commons Attribution 4.0 International License (http://creativeco mmons.org/licenses/by/4.0/), which permits unrestricted use, distribution, and reproduction in any medium, provided you give appropriate credit to the original author(s) and the source, provide a link to the Creative Commons license, and indicate if changes were made.

\section{References}

1. Moya A, Peretó J, Gil R, Latorre A (2008) Learning how to live together: genomic insights into prokaryote-animal symbioses. Nature Rev Gen 9:218-229. https://doi.org/10.1038/nrg2319

2. Stewart EJ (2012) Growing unculturable bacteria. J Bacteriol 194:4151-4160. https://doi.org/10.1128/JB.00345-12

3. Douglas AE (2016) How multi-partner endosymbiosis function. Nat Rev Microbiol 14:731-743. https://doi.org/10.1038/nrmic ro.2016.151

4. Duplouy A, Hornett EA (2018) Uncovering the hidden players in Lepidoptera biology: the heritable microbial endosymbionts. PeerJ. 6:e4629. https://doi.org/10.7287/peerj.preprints.26768v1

5. Ye Z, Vollhardt IMG, Parth N, Rubbmark O, Traugott M (2018) Facultative bacterial endosymbionts shape parasitoid food webs in natural host populations: a correlative analysis. J Anim Ecol 87:1440-1451. https://doi.org/10.1111/1365-2656.12875

6. Li Y, Liu X, Guo H (2018) Variations in endosymbiont infection between buprofezin-resistant and susceptible strains of Laodelphax striatellus (Fallén). Curr Microbiol 75:709-715. https://doi. org/10.1007/s00284-018-1436-x

7. Norton RA, Palmer SC (1991) The distribution, mechanisms and evolutionary significance of parthenogenesis in oribatid mites. In: Schuster R, Murphy W (eds) The Acari: reproduction, development and life-history strategies. Chapman \& Hall, London, UK, pp 107-136

8. Konecka E, Olszanowski Z (2015) A screen of maternally inherited microbial endosymbionts in oribatid mites (Acari: Oribatida). Microbiol (SGM) 161:1561-1571. https://doi.org/10.1099/ mic. 0.000114

9. Liana M, Witaliński W (2010) Microorganisms in the oribatid mite Hermannia gibba (C. L. Koch, 1839) (Acari: Oribatida: Hermanniidae). Biol Lett 47:37-43. https://doi.org/10.2478/v1012 0-009-0018-9

10. Konecka E, Olszanowski Z (2019) A new Cardinium group of bacteria found in Achipteria coleoptrata (Acari: Oribatida). Mol Phylogen Evol 131:64-71. https://doi.org/10.1016/j.ympev .2018 .10 .043

11. Ma WJ, Schwander T (2017) Patterns and mechanisms in instances of endosymbiont-induced parthenogenesis. J Evolution Biol 30:868-888. https://doi.org/10.1111/jeb.13069

12. Tomassone L, Portillo A, Nováková M, de Sousa R, Oteo JA (2018) Neglected aspects of tick-borne rickettsioses. Parasit Vectors 11:263. https://doi.org/10.1186/s13071-018-2856-y

13. van der Kooi CJ, Matthey-Doret C, Schwander T (2018) Evolution and comparative ecology of parthenogenesis in haplodiploid arthropods. Evol Lett 1-6:304-316. https://doi.org/10.1002/ evl3.30

14. Cordaux R, Bouchon D, Gréve P (2011) The impact of endosymbionts on the evolution of host sex-determination mechanisms. Trends Genet 27:332-341. https://doi.org/10.1016/j. tig.2011.05.002

15. Dykstra HR, Weldon SR, Martinez AJ, White JA, Hopper KR, Heimpel GE (2014) Factors limiting the spread of the protective symbiont Hamiltonella defensa in Aphis craccivora aphids. Appl Environ Microbiol 80:5818-5827. https://doi.org/10.1128/ AEM.01775-14

16. Correa CC, Ballard JWO (2016) Wolbachia associations with insects: winning or losing against a master manipulator. Front Ecol Evol 3:153. https://doi.org/10.3389/fevo.2015.00153 
17. Tan CH, Wong PJ, Ll MI, Yang H, Ching L, O’Neill SL (2017) $w \mathrm{Mel}$ limits zika and chikungunya virus infection in a Singapore Wolbachia introgressed Ae. aegypti strain, wMel-Sg. PLoS Negl Trop. Dis 19:1-10. https://doi.org/10.1371/journal.pntd.00054 96

18. Lorenzo-Carballa MO, Cordero-Rivera A (2009) Thelytokous parthenogenesis in the damselfly Ischnura hastata (Odonata, Coenagrionidae): genetic mechanisms and lack of bacterial infection. Heredity 103:377-384. https://doi.org/10.1038/hdy.2009.65

19. Chang J, Masters A, Avery A, Werren JH (2010) A divergent Cardinium found in daddy long-legs (Arachnida: Opiliones). J Invert Pathol 105:220-227. https://doi.org/10.1016/j.jip.2010.05.017

20. Giorgini M, Bernardo U, Monti MM, Nappo AG, Gebiola M (2010) Rickettsia symbionts cause parthenogenetic reproduction in the parasitoid wasp Pnigalio soemius (Hymenoptera: Eulophidae). Appl Environ Microbiol 76:2589-2599. https://doi. org/10.1371/journal.pone.0004767

21. Tabata J, Hattori Y, Sakamoto H, Yukuhiro F, Fujii T, Kugimiya S, Mochizuki A, Ishikawa Y, Kageyama D (2011) Male killing and incomplete inheritance of a novel Spiroplasma in the moth Ostrinia zaguliaevi. Microb Ecol 61:254-263. https://doi. org/10.1007/s00248-010-9799-y

22. Raina HS, Rawal V, Singh S, Daimei G, Shakarad M, Rajagopal R (2015) Elimination of Arsenophonus and decrease in the bacterial symbionts diversity by antibiotic treatment leads to increase in fitness of whitefly, Bemisia tabaci. Infect Gen Evol 32:224-230. https://doi.org/10.1016/j.meegid.2015.03.022

23. Pan H, Li X, Zhang Y (2012) Sex affects the infection frequencies of symbionts in Bemisia tabaci. Commun Integr Biol 5:337-339. https://doi.org/10.4161/cib.20398

24. Nakamura Y, Kawai S, Yukuhiro F, Ito S, Gotoh T, Kisimoto R, Yanase T, Matsumoto Y, Kageyama D, Noda H (2009) Prevalence of Cardinium bacteria in planthoppers and spider mites and taxonomic revision of "Candidatus Cardinium hertigii" based on detection of a new Cardinium group from biting midges. Appl Environ Microbiol 75:6757-6763. https://doi.org/10.1128/ AEM.01583-09

25. Edlund A, Ek K, Breitholtz M, Gorokhova E (2012) Antibioticinduced change of bacterial communities associated with the copepod Nitocra spinipes. PLoS ONE 7:e33107. https://doi. org/10.1371/journal.pone.0033107

26. Santos-Garcia D, Rollat-Farnier PA, Beitia F, Zchori-Fein E, Vavre F, Mouton L, Moya A, Latorre A, Silva FJ (2014) The genome of Cardinium cBtQ1 provides insights into genome reduction, symbiont motility, and its settlement in Bemisia tabaci. Genome Biol Evol 6:1013-1030. https://doi.org/10.1093/gbe/ evu077

27. Weigmann G (2006) Hornmilben (Oribatida). In: Dahl F (ed) Die Tierwelt Deutschlands, vol 76. Goecke \& Evers, Keltern, pp $1-520$

28. Tiawsirisup S, Sripatranusorn S, Oraveerakul K, Nuchprayoon S (2008) Distribution of mosquito (Diptera: Culicidae) species and Wolbachia (Rickettsiales: Rickettsiaceae) infections during the bird immigration season in Pathumthani province, central Thailand. Parasitol Res 102:731-735. https://doi.org/10.1007/s0043 6-007-0825-Z

29. Hornok S, Földvári G, Elek V, Naranjo V, Farkas R, de la Fuente J (2008) Molecular identification of Anaplasma marginale and rickettsial endosymbionts in blood-sucking flies (Diptera: Tabanidae, Muscidae) and hard ticks (Acari: Ixodidae). Vet Parasitol 154:354-359. https://doi.org/10.1016/j.vetpar.2008.03.019

30. Zchori-Fein E, Perlman SJ (2004) Distribution of the bacterial symbiont Cardinium in arthropods. Mol Ecol 13:2009-2016. https ://doi.org/10.1111/j.1365-294X.2004.02203.x

31. De Luna CJ, Moro CV, Guy JH, Zenner L, Sparagano OAE (2009) Endosymbiotic bacteria living inside the poultry red mite
(Dermanyssus gallinae). Exp Appl Acarol 48:105-113. https:// doi.org/10.1007/s10493-008-9230-2

32. Webb L, Carl M, Malloy DC, Dasch GA, Azad AF (1990) Detection of murine typhus infection in fleas by using the polymerase chain reaction. J Clin Microbiol 28:530-534

33. Thao ML, Baumann P (2004) Evidence for multiple acquisition of Arsenophonus by whitefly species (Sternorrhyncha: Aleyrodidae). Curr Microbiol 48:140-144. https://doi.org/10.1007/s0028 4-003-4157-7

34. Moran NA, Degnan PH, Santos SR, Dunbar HE, Ochman H (2005) The players in a mutualistic symbiosis: insects, bacteria, viruses, and virulence genes. PNAS 102:16919-16926. https:// doi.org/10.1073/pnas.0507029102

35. Fredriksson NJ, Hermansson M, Wilén BM (2013) The choice of PCR primers has great impact on assessments of bacterial community diversity and dynamics in a wastewater treatment plant. PLoS ONE 8:e76431. https://doi.org/10.1371/journal.pone.00764 31

36. Tamura K, Peterson D, Peterson N, Stecher G, Nei M, Kumar S (2011) MEGA5: molecular evolutionary genetics analysis using maximum likelihood, evolutionary distance, and maximum parsimony methods. Mol Biol Evol 28:2731-2739. https://doi. org/10.1093/molbev/msr121

37. Posada D, Crandall KA (1998) MODELTEST: testing the model of DNA substitution. Bioinf 14:817-818. https://doi.org/10.1093/ bioinformatics/14.9.817

38. Zchori-Fein E, Perlman SJ, Kelly SE, Katzir N, Hunter MS (2004) Characterization of a 'Bacteroidetes' symbiont in Encarsia wasps (Hymenoptera: Aphelinidae): proposal of 'Candidatus Cardinium hertigii'. Int J Syst Evol Microbiol 54:961-968. https://doi. org/10.1099/ijs.0.02957-0

39. Chu D, Gao CS, De Barro P, Zhang YJ, Wan FH, Khan IA (2011) Further insights into the strange role of bacterial endosymbionts in whitefly, Bemisia tabaci: Comparison of secondary symbionts from biotypes B and Q in China. Bull Entomol Res 101:477-486. https://doi.org/10.1017/S0007485311000083

40. Gonella E, Pajoro M, Marzorati M, Crotti E, Mandrioli M, Pontini M, Bulgari D, Negri I, Sacchi L, Chouaia B, Daffonchio D, Alma A (2015) Plant-mediated interspecific horizontal transmission of an intracellular symbiont in insects. Sci Rep 5:15811. https://doi. org/10.1038/srep15811

41. Fang YW, Liu LY, Zhang HI, Jiang DF, Chu D (2014) Competitive ability and fitness differences between two introduced populations of the invasive whitefly Bemisia tabaci Q in China. PLoS ONE 9:e100423. https://doi.org/10.1371/journal.pone.0100423

42. Penz T, Schmitz-Esser S, Kelly SE, Cass BN, Müller A, Woyke T, Malfatti SA, Hunter MS, Horn M (2012) Comparative genomics suggests an independent origin of cytoplasmic incompatibility in Cardinium hertigii. PLoS Gen 8:e1003012. https://doi. org/10.1371/journal.pgen.1003012

43. Smelansky I (2006) Some population characteristics of oribatid mites in steppe habitats. Acarina 14:123-130

44. Krisper G, Schuster R (2016) Erstnachweise bodenbewohnender und arboricoler Milbenarten in österreichischen Bundesländern (Acari: Oribatida). Mitt Naturwiss Ver Steiermark 145:69-74

45. Subías LS (2017) Listado sistemático, sinonímico y biogeográfico de los Ácaros Oribátidos (Acariformes: Oribatida) del mundo (Excepto fósiles) (12 actualización). Graellsia 60:3-305

46. Wypych A, Sulikowska A, Ustrnul Z, Czekierda D (2017) Variability of growing degree days in Poland in response to ongoing climate changes in Europe. Int J Biometeorol 61:49-59. https:// doi.org/10.1007/s00484-016-1190-3

47. Wang X, Xu HX, Liu SP, Tang JW, Zheng XS, Lv ZX (2016) Influence of temperature on symbiotic bacterium composition in successive generations of egg parasitoid, Anagrus nilaparvatae. Rice Sci 23:203-210. https://doi.org/10.1016/j.rsci.2016.06.003 
48. Vyskočilová S, Tay WT, van Brunschot S, Seal S, Colvin J (2018) An integrative approach to discovering cryptic species within the Bemisia tabaci whitefly species complex. Sci Rep 8:10886. https ://doi.org/10.1038/s41598-018-29305-w1

49. Konjević A, Milovac Ž, Kontsedalov S, Kanakala S, Ghanim M (2018) First interception of Bemisia tabaci Mediterranean (Q biotype) in Serbia. J Appl Entomol 142:627-631. https://doi. org/10.1111/jen. 12508
Publisher's Note Springer Nature remains neutral with regard to jurisdictional claims in published maps and institutional affiliations. 